\title{
Endometriosis vesical
}

\author{
Giménez Bachs JM, Pastor Guzmán JM, Donate Moreno MJ, Pastor Navarro H, \\ Carrión López P, Virseda Rodríguez JA.
}

Servicio de Urología. Complejo Hospitalario Universitario de Albacete.

Actas Urol Esp. 2007;31(8):940

$\mathrm{M}$ ujer de 33 años remitida desde consulta de infertilidad por sospecha de endometriosis vesical, habiendo sido diagnosticada previamente de endometriosis tubárica. Presenta leve clínica miccional coincidiendo con la menstruación, aunque no hematuria. Tras realizar ecografia en la que se ve imagen excrecente vesical, así como citología de orina negativa para células tumorales, se procede a endoscopia vesical bajo anestesia en la que se observa protusón de la mucisa vesical por probable endometrioma vesical y a la resección del

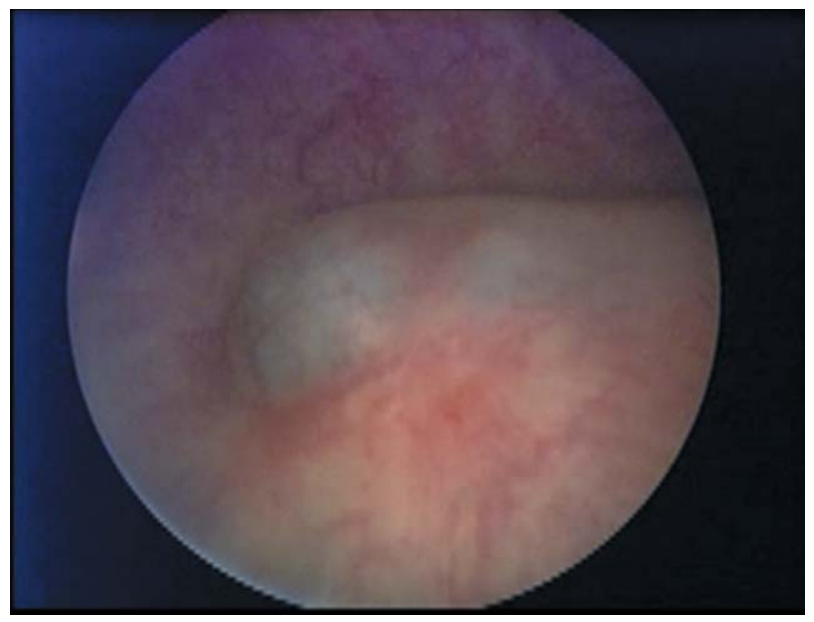

FIGURA 1 mismo salida de contenido "achocolatado", tal y como se muestra en las Figuras 1 y 2. El resultado histológico de la biopsia confirma el diagnóstico de endometriosis vesical.

Correspondencia autor: Dr. J.M. Giménez Bachs

Servicio de Urología. Complejo Hospitalario Universitario de Albacete. Hermanos Falcó, 37 - 02006 Albacete

Tel.: 967597100

E-mail autor: gbjosem@sescam.jccm.es

Información artículo: Imágenes en Urología

Trabajo recibido: julio 2006

Trabajo aceptado: septiembre 2006

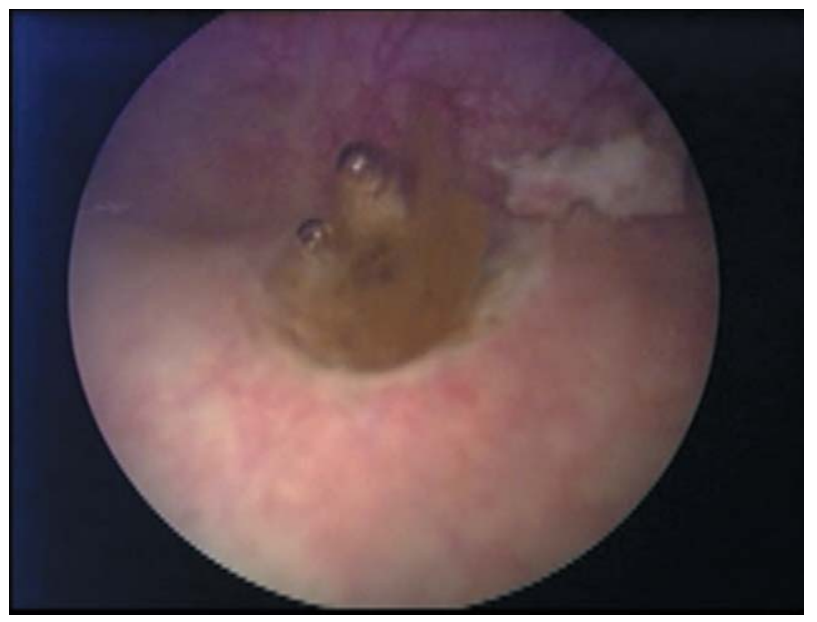

FIGURA 2 